\title{
6 Information structure
}

Information structure is one of the most often discussed strategies to achieve definiteness in articleless languages. This chapter is structured as follows: Section 6.1 provides the theoretical background for this chapter. How information structure, definiteness, and the concept types in Polish interact is the focus of section 6.2. In section 6.3, Polish is compared to other Slavic languages. I will restrict my discussion to NPs in declarative sentences.

\subsection{Theoretical background}

The first section explains what information structure is. Section 6.1.2 is concerned with the thetic/categorical distinction. Mathesius' and Lambrecht's definitions of the bipartite structure of categorical sentences will be discussed in sections 6.1 .3 and 6.1.4, respectively.

\subsubsection{What is information structure?}

Information structure, a term introduced by Halliday (1967), also called 'functional sentence perspective' by the linguists of the Prague School such as Mathesius (1929), concerns the packaging of information in a sentence or utterance. Therefore, it is about the way we convey information and not what the content is about (Chafe 1976: 27). The aim is to achieve an optimal transfer of information. Example (1) displays an optimal information packaging since a referent of the NP a new car is introduced in the first sentence and afterwards the personal pronoun it is used that refers back to it. If the personal pronoun were used before introducing the car to which the pronoun refers, we would not have an optimal transfer because the hearer would not know to which referent the pronoun refers at the moment of perceiving the first sentence. 
(1) I bought a new car. It was very expensive.

Depending on the background and aim of the conversation, the information has to be structured differently. Although the sentences in (2) have the same content, they differ in the packaging of information, resulting from a different word order and the different placement of sentence stress. Only the sentence in (2b) is an appropriate answer to the question Where did Mary fly yesterday? Why only this sentence is an appropriate answer will be discussed in the following sections.

(2) a. Mary flew to London YESTERDAY.

b. To LONDON Mary flew yesterday.

c. Yesterday, MARY flew to London.

\subsubsection{Thetic sentences}

The distinction between thetic and categorical ${ }^{1}$ is crucial when discussing information structure. Thetic sentences are undivided and the sentence only comprises new information (Sasse 1987, Lambrecht 1994: 144, Rosengren 1997). As Rosengren (1997: 439) points out, the sentence is "all-focused and all-comment", which means that the sentence consists only of new information. Detailed definitions of the terms 'comment' and 'focus' are discussed in the following two sections. In Polish, declarative intransitive sentences with a VS structure are thetic (3a). The subjects of thetic sentences can also be preverbal, but they have to bear the sentence stress (3b) (cf. Lenertová \& Junghanns: 2007: 398f.).

(3)
a. Umart STUDENT.
die.PST.3SG student
'A/the student died.'
b. STUDENT umart.
student die.PST.3SG
'A/the student died.'

The terminological distinction goes back to Brentano and Marty at the end of the 19th century (Sasse 1987: 511). 
As (3) shows, thetic sentences can comprise definite NPs since student 'student' can have a definite or indefinite reading depending on whether its referent was mentioned earlier in the discourse or is definite due to the speech situation. Furthermore, the NP student 'student' can be replaced by the IN papiez 'pope' and only a definite interpretation would be available, which would not change the thetic status of the sentence.

\subsubsection{Mathesius' (1929) definition of theme and rheme}

In contrast to thetic sentences, categorical sentences are bipartite (Rosengren 1997: 439). There are different terms for the two parts of the sentence such as topic-comment, theme-rheme, background-focus, and many more. As one of the first authors, Mathesius (1929, 1975), analysing English and Czech, pointed out that a sentence or utterance can normally be divided into a theme and a rheme ${ }^{2}$. He goes on to define them as follows:

One part expresses what is given by the context or what naturally presents itself, in short what is being commented upon. [...] this part is called the theme of the utterance. The second part contains the new element of the utterance, i. e. what is being stated about something; this part is called the rheme of the utterance. The usual position of the theme of an utterance is the beginning of the sentence, whereas the rheme occupies a later position, i.e. we proceed from what is already known to what is being made known. (Mathesius 1975: 156 [1961])

In his definition of theme and rheme, three factors play a role (i) aboutness, (ii) new/given information, and (iii) position within the sentence. If we apply Mathesius' definition of theme and rheme to example (4), Robert in the second sentence represents the theme because it is at the beginning of the sentence, given information due to its previous mention and it is commented upon, namely that he ate an apple. In contrast, ate an apple is the rheme being at the end of the sentence, it is new information and it says something about Robert.

According to Bogusławski (1977: 7, note 1) the terms 'theme' and 'rheme' were introduced by Ammann (1911). 
What did Robert do? Robert ate an apple.

Since Mathesius, various approaches to information structure have been developed. For a detailed overview of the various approaches see von Heusinger (2002b), who also summarizes the different terms which are used for the bipartite structure defined by Mathesius. It has to be stressed that there is no generally accepted definition of the bipartite structure.

\subsubsection{Lambrecht's (1994) definition of topic and focus}

I follow Lambrecht's (1994) definition of topic and focus for the bipartite structure because it is widespread and also used in syntactic theories such as Role and Reference Grammar by Van Valin (1993: 23f.; 2005, chapter 3) and Van Valin \& LaPolla (1997, chapter 5). Lambrecht defines topic as follows:

The topic of a sentence is the thing which the proposition expressed by the sentence is ABOUT" (Lambrecht 1994: 118). [...] "If a topic is seen as a matter of standing interest or concern, a statement about a topic can count as informative only if it conveys information which is RELEVANT with respect to this topic (Lambrecht 1994: 119).

There is an inherent relationship between topic and pragmatic presupposition (5):

"PRAGMATIC PRESUPPOSITION: The set of propositions lexicogrammatically evoked in a sentence which the speaker assumes the hearer already knows or is ready to take for granted at the time the sentence is uttered." (Lambrecht 1994: 52)

From the definition of the topic, which is connected to aboutness and relevance, it follows that the topic must be part of the pragmatic presupposition since it is already under discussion (Lambrecht 1994: 150). Example (6) is to illustrate Lambrecht's definition of topic.

(6) (What did the children do next?) The children went to SCHOOL. (Lambrecht 1994: 121) 
In (6), the sentence is about the referent of the NP the children and it adds to the addressee's knowledge about the children, namely that they went to school. Furthermore, the sentence pragmatically presupposes that the children are a "matter of standing current interest and concern" (Strawson 1964: 97), because they are under discussion and taken for granted due to their previous mention. This is why the NP the children is the topic of the sentence.

The topic of a sentence can only be determined if the discourse context is taken into consideration since one has to know what is already presupposed and under discussion (Lambrecht 1994: 120). For this reason, Lambrecht makes use of the question-answer test as in (6). The NP the children is the topical NP in the answer because its referent is mentioned in the question and thus is already established and taken for granted in the answer. There are also other tests which help to determine the topic and focus of a sentence (Bogusławski 1977: 183f.; van Dijk 1977: 116f.; Reinhart 1981: 56f., 64f.; Nilsson 1982: 3). In (6), we saw that we can ask for the focus. The focus in (6) is went to school. Furthermore, topical NPs can be pronominalized. This is shown in (7) with Lambrecht's modified example:

$$
\text { (What did the children do next?) They went to SCHOOL. }
$$

For Lambrecht (1994: 200f.), it is the aboutness and relevance aspects that are crucial for defining a topic, and not the syntactic position as is assumed, for example, by Halliday (1967: 212) or Mathesius as shown above. $^{3}$ Lambrecht (1994: 118, 146ff.) also points out that the grammatical subject does not necessarily have to be the topic. This will also be supported by the Polish data in section 6.2. The focus is defined by Lambrecht as follows.

$3 \quad$ Lambrecht (1994: 200f.) provides arguments against the claim that the first constituent of a sentence is the topic, such as the change of sentence stress to the first constituent. Furthermore, there are languages with an unmarked focus-topic structure such as in Toba Batak, an Austronesian language with a strict VOS word order. For a detailed discussion of Toba Batak see Van Valin (1999: 518-520). 
The focus is that portion of a proposition which cannot be taken for granted at the time of speech. It is the UNPREDICTED or pragmatically NON-RECOVERABLE element in an utterance. The focus is what makes an utterance into an assertion. (Lambrecht 1994: 207)

PRAGMATIC ASSERTION: The proposition expressed by a sentence which the hearer is expected to know or take for granted as a result of hearing the sentence uttered. (Lambrecht 1994: 52)

The focus is the part of the proposition which is asserted or added. The added proposition in (6) is that the referent of the topical NP the children went to school.

Lambrecht (1994: 221ff.) proposes a classification of different focus structures into argument, predicate, and sentence focus. ${ }^{4}$ As the term reveals, with predicate focus the predicate is the focus while the subject is the topic, which is shown by Lambrecht's example in (8). The NP my car serves as the topic because it is given information. The referent of the topical NP is already mentioned in the question. The predicate broke down is the focus. So we have a topic-focus structure.

$$
\begin{aligned}
& \text { What happened to your car? } \\
& \text { My car/it broke DOWN. } \\
& \text { (Lambrecht 1994: 223) }
\end{aligned}
$$

In sentence focus constructions, the whole sentence represents the focus and no topic is present (9). Such sentences were called 'thetic' at the beginning of this chapter.

(9) What happened?

My CAR broke down.

(Lambrecht 1994: 223)

With argument focus, only one constituent is the focus such as in (10) the NP my car. The constituent can be a subject or an object NP. The 
topic is broke down since it is already mentioned in the question and thus taken for granted.

\section{I heard your motorcycle broke down? My CAR broke down.}

(Lambrecht 1994: 223)

In (10), the NP my car is the focus due to bearing the sentence stress ${ }^{5}$ and not being granted for the hearer. In (10), we have a focus-topic structure due to the sentence stress on car.

After the definition of topic and focus, I will discuss how definiteness is related to it. If the topic is a presupposed or given proposition and taken for granted, this would mean that topical NPs must be definite or generic. This is substantiated by Gundel's (1988) cross-linguistic investigation of 30 languages. She comes to the conclusion that "the topic of a sentence is typically definite or generic" (Gundel 1988: 213). However, focal NPs cannot automatically be associated with indefiniteness. They can be definite or indefinite as pointed out by Lyons (1999: 232f.). This is illustrated by a Japanese example in (11), in which the topical NP neko 'cat' marked by the topic marker wa can only be definite in contrast to the focal NP kingyo 'goldfish' which allows a definite and indefinite reading.

(11) Japanese (Gundel 1988: 213)

Neko wa kingyo o ijitte iru.

cat TOP goldfish OBJ play_with AUX

'The/*a cat is playing with the/a goldfish.'

According to Chafe (1976: 31), the focus is more stressed than the topic, which means that the added proposition is highlighted.

The example has been adapted by adding the auxiliary verb iru. Otherwise, the sentence is incomplete, according to Yuka Höfler (p.c.). 


\subsection{Information structure in Polish}

In the following, I will show that the information structure, or topicfocus structure, of a Polish sentence is associated with word order and the placement of sentence stress. ${ }^{7}$ In section 6.2.1, I will present the unmarked topic-focus structure in Polish and how this interacts with definiteness. Section 6.2.2 deals with the results of a quantitative study by Czardybon et al. (2014), which supports my claim that not every preverbal NP has to be interpreted as definite or generic, but there is a complex interaction between word order, information structure, and definiteness. How the concept types interact with information structure in Polish is focused on in section 6.2.3, followed by a discussion of the interaction and ranking of information structure, concept types, and explicit markers of (in)definiteness.

\subsubsection{The unmarked topic-focus structure and its influence on definiteness}

In Polish, the topic is normally found preverbally whereas the focus is post-verbal, i.e. in an unmarked sentence, the topic precedes the focus in Polish (Engel et al. 1999: 494f., Grzegorek 1984: 22, 92, Ożóg 1990: 142, Szwedek 1976b: 62). For illustration, an example taken from the Polish National Corpus is given in (12):

$$
\begin{aligned}
& \text { Kobiet-a znalazła dom. } \\
& \text { woman-NOM find.PST house } \\
& \text { 'The woman found a house.' }
\end{aligned}
$$

\footnotetext{
In Polish, there are no morphological markers for topics such as in Japanese or focus markers such as in the Indo-Iranian language Marathi or Duala, a Bantu language (For a discussion see Gundel 1988: 220-221). However, there are lexical means such as in English as for, as concerns or their Polish equivalents such as jeżeli/jeśli chodzi/idzie o, co się tyczy, co do, odnośnie, which introduce the topic, but will not be discussed here. For a discussion see Grochowski (1984) and Ożóg (1990: 142f.).
} 
In (12), the preverbal NP kobieta 'woman' is the topic of the sentence. She is taken for granted and under discussion since she is given by the context due to a previous mention. As a topical NP, kobieta 'woman' could also be pronominalized by ona 'she' or the NP could be completely omitted. The NP dom 'house' is focal because it is a new piece of information which is not mentioned in the previous context or part of the speech situation. As mentioned above, only within a given context of utterance is it possible to determine the topic and the focus of a sentence.

For Polish, Błaszczak, among others, points out that "in a post-verbal position (i.e., in the so-called rhematic part of a sentence) a nominal phrase not accompanied by any determiner (i.e., any indefinite or demonstrative pronoun) is in principle ambiguous (definite or indefinite)" (Błaszczak 2001:11). Furthermore, she writes that "[i]n a preverbal position a nominal is normally interpreted as definite" (Błaszczak 2001:15). ${ }^{8}$ It is crucial to say that Błaszczak's observation only holds if we have an unmarked sentence stress, which is towards the end of the sentence (Szwedek 1975: 101f.; Szwedek 1976a: 80f.; Gebert 2009: 308). Example (12) is taken from written Polish, where sentence stress is not indicated. The focal NP only has an indefinite reading in this example. However, Błaszczak is correct in claiming that in general focal NPs can also be definite. This is shown in (13) which is a modification of example (12):

Kobiet-a znalazła DOM. woman-NOM find.PST house.ACC 'The/(“a) woman found a/the house.'

$8 \quad$ In Polish, topics can also be generic as in (i). The topical NP tramwaj 'tram' refers to the whole class of trams and not to an individual one. In the following discussion, generic NPs as topics will not be taken into consideration.

(i) Tramwaj jest środkiem komunikacji miejskiej. tram COP means_of_transport municipal 'The tram is a means of public transport.' 
In Polish, as in most Slavic languages, the word order can be changed due to its rich case morphology (Sussex \& Cubberley 2006: 404f.). This has already been demonstrated in the previous chapter on differential object marking and case alternation. The unmarked word order is SVO in Polish as in (13), but all six word order combinations are possible (14). Siewierska \& Uhliřrová (1998: 107f., 121) analyse the word order of transitive sentences in Polish based on a corpus of written Polish with 1450 clauses and they state that in about $69 \%$ SVO is found.
a. OVS
Dom znalazła KOBIET-A.
house.ACC find.PST woman-NOM
'The/a woman found the/(*a) house.'
b. SOV
Kobiet-a dom ZNALAZEA.
woman-NOM house.ACC find.PST
'The/("a) woman found the/("a) house.'
c. OSV
Dom kobiet-a ZNALAZEA.
house.ACC woman-NOM find.PST
'The/("a) woman found the/("a) house.'
d. VSO
Znalazła kobiet-a DOM.
find.PST woman-NOM house.ACC
'A/the woman found a/the house.'
e. VOS
Znalazta dom KOBIET-A.
find.PST house.ACC woman-NOM
'A/the woman found a/the house.'

The five sentences in (14) differ in what is the topic and what the focus in the sentences. This also means that they differ in the context they can occur. All preverbal unstressed NPs are topical NPs. In (14a), it is the NP dom 'house', in (14b) and (14c) the NPs dom 'house' and kobieta 'woman', and in (14d) and (14e) we have thetic sentences with no topical NPs. All topical NPs are interpreted as definite, whereas the focal NPs, which 
are post-verbal, allow for a definite or indefinite reading. In all sentences, we assume to have an unmarked sentence stress at the end of the sentence. These examples show that in Polish it is possible to topicalize NPs by placing them preverbally. It is also vital to emphasize that the definiteness restriction which is observed in (14) is only found with bare NPs, i.e. without any determiners such as demonstratives (ten, tamten, ów, taki), indefinite (jakiś 'some', jakikolwiek 'any', niektóry 'some', niejaki 'some', jeden 'one' (cf. Mendoza 2004)), or possessive pronouns, as well as quantifiers (wszystek 'all', wiele/dużo 'many/much', kilka 'a few/several', pare 'a few'). This is also part of Blaszczak's (2001) observation given above. In (15), the numeral jeden 'one' explicitly marks the preverbal noun plakat 'poster' as indefinite. The whole sentence is focal and thus we have a thetic sentence.

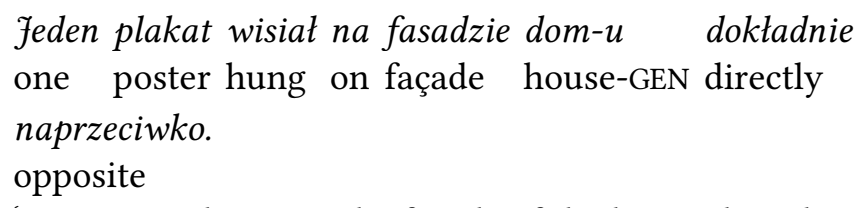

'One poster hung on the façade of the house directly opposite.' (Orwell, translated by Mirkowicz 2008: 8)

\subsubsection{Czardybon et al.'s (2014) study on word order and definiteness}

Czardybon et al. (2014) carried out a quantitative study to investigate the interaction between word order and definiteness in Polish and to see whether the previous qualitative studies can be substantiated. The question was: Is the definiteness of an NP associated with the position of the $\mathrm{NP}$ relative to the main verb? They made use of an annotated text sample of the first 479 sentences of the Polish translation of George Orwell's novel Nineteen Eighty-Four. ${ }^{9}$ Two native speakers of Polish did the annotation work and had to decide whether the NPs are definite or indefi-

$9 \quad$ The sentences were split into syntactic chunks and only sentences/clauses with exactly one main verb were used for the further investigation. Sentences with auxiliary verbs were excluded. This is why only about $47 \%$ of the data could be used, which was also due to unclear chunkings of the sentences (Czardybon et al. 2014: 147). 
nite. ${ }^{10}$ Furthermore, in unclear cases they could choose the option "I don't know". Only bare NPs were used for this study, whereby 101 nouns were excluded due to the presence of demonstratives, indefinite, and possessive pronouns, numerals, quantifiers, superlatives, and ordinals (Czardybon et al. 2014: 146f.). The syntactic position and definiteness of the remaining 623 nouns is given in table 21:

\begin{tabular}{|l|c|c|}
\hline & preverbal position & post-verbal position \\
\hline definite & 197 & 222 \\
\hline indefinite & 49 & 155 \\
\hline
\end{tabular}

Table 21: Correlation between syntactic position and definiteness of NPs (Czardybon et al. 2014: 147).

The results are statistically significant and show that the preverbal position is strongly connected to definiteness with 197 definite vs. 49 indefinite NPs. Indefinite NPs are predominantly found in post-verbal position with 155 NPs vs. 49 indefinite preverbal NPs. However, in post-verbal position we also find 222 definite NPs. This shows that there is no syntactic preference for definite NPs. ${ }^{11}$ Thus, this investigation supports the claims of earlier qualitative studies that in the post-verbal position definite and indefinite NPs can be found. The high number of preverbal indefinite NPs is unexpected. About $20 \%$ of all preverbal NPs are indefinite (Czardybon et al. 2014: 148f.).

One possible explanation for the high number of indefinite preverbal NPs could be that partitive constructions are used in the preverbal position. They can serve as topics because, although the whole construction is indefinite, there is a definite superset involved. In contrast to the bare partitive NPs discussed in chapter 5 , the subset can be expressed explicitly such as by the numeral jedna 'one' as in (16). The superset dziewczyny

\footnotetext{
10 Generic NPs were not included in the category for definite NPs, but there was a separate category for them.

11 In the next section, I will show that inherently unique nouns in congruent and bare use are interpreted as definite independent of their syntactic position. This is why the concept types of the nouns given in table 21 have been annotated to provide a better picture of the connection between the syntactic position, concept types, and definiteness. The results are given in the next section.
} 
'girls' is definite, in this case marked by a demonstrative, which is optional in such examples.

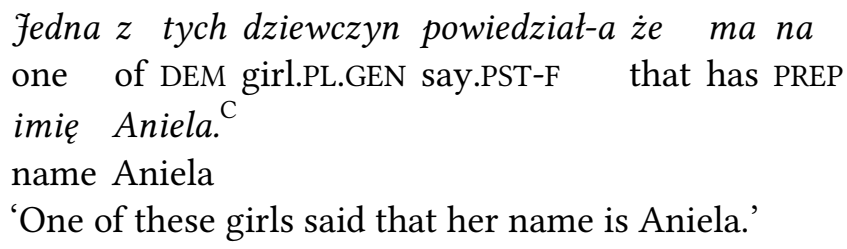

However, I checked the text sample of Czardybon et al. (2014) and none of the 49 indefinite preverbal NPs is a partitive construction. The explanation for the preverbal indefinite NPs is that they are focal since indefinite NPs implicate focal NPs. As I have argued above, focal NPs can be definite or indefinite. In (17), the preverbal indefinite NP helikopter 'helicopter' is part of a thetic sentence. The referents of the sentence are not taken for granted or under discussion up to this point and thus the whole sentence is focal.

$$
\begin{aligned}
& \text { helikopter zniżyt sie pomiędzy dachy [...] } \\
& \text { helicopter skim_down REFL between roofs } \\
& \text { 'a helicopter skimmed down between the roofs [...]' } \\
& \text { (Orwell, translated by Mirkowicz 2008: 8) }
\end{aligned}
$$

A similar situation is found in (18), which also represents a thetic sentence. The focal NP sygnat trabki 'trumpet call' has an indefinite reading and would bear the sentence stress in spoken Polish. This again shows that the claim that all preverbal NPs have to be interpreted as definite does not apply to thetic sentences, but only to categorical ones with an unmarked information structure. Consequently, thetic sentences should be excluded from the investigation. In my text sample, 18 of the 49 indefinite preverbal NPs (and thus about $40 \%$ ) are part of thetic sentences.

$$
\text { Sygnat trabk-i, czysty } i \text { piękny, przeciąt }
$$

signal trumpet-GEN clear and beautiful cut_through.PST

zatęchte powietrze.

stagnant air

'A trumpet call, clear and beautiful, floated into the stagnant air.'

(Orwell, translated by Mirkowicz 2008: 33) 
In spoken Polish, stressing the preverbal NP leads to argument focus $(19 b)^{12}$ and thus changes the unmarked topic-focus structure (19a). This has also an influence on the definiteness of the NPs. In (19a), the topical NP kobieta 'woman' is preverbal and unstressed and thus can only be interpreted as definite. In (19b), the preverbal NP bears the sentence stress, which leads to argument focus and the fact that the NP can have a definite or indefinite reading. This shows that the topic-focus structure can be overwritten by sentence stress. ${ }^{13}$
a. Kobiet-a kupi-t-a KSIĄŻK-Ę. woman-NOM buy-PST-F book-ACC 'The/(*a) woman bought a/the book.'
b. KOBIET-A kupi-t-a ksiażk-ę. woman-NOM buy-PST-F book-ACC 'The/a woman bought the book.'

What has been shown so far is that topical NPs in Polish can be found preverbally, which is the unmarked position for topics, and postverbally, but they never bear the sentence stress. Focal NPs can also occur pre- and post-verbally, but their unmarked position is post-verbal. This shows that the relevant feature for the explanation of the distribution of definite and indefinite NPs is not the syntactic position, although there is a tendency due to the unmarked position of topical NPs, but it is the distinction between topical and focal NPs. Topical NPs are definite ${ }^{14}$ whereas focal NPs can be definite or indefinite. This is summarized in table 22 . For more information on the interaction between sentence stress and word order in Polish, see Szwedek (1974, 1976a). which are not of interest here and are thus neglected.
} 


\begin{tabular}{|l|c|c|}
\hline & Preverbal NP & \multicolumn{1}{|c|}{ Post-verbal NP } \\
\hline Stressed NP & $\begin{array}{r}\text { Focus: definite/ } \\
\text { indefinite }\end{array}$ & $\begin{array}{c}\text { Focus: definite/ } \\
\text { indefinite }\end{array}$ \\
\hline Unstressed NP & Topic: definite & $\begin{array}{l}\text { Focus: definite/indefinite } \\
\text { Topic: definite }\end{array}$ \\
\hline
\end{tabular}

Table 22: Interaction between word order, sentence stress, and definiteness of the Polish bare NP.

In the literature, there are often incorrect observations with regard to preverbal NPs and their (in)definite interpretation. Weiss (1983: 235) and Topolinjska (2009: 184f.) argue that it is a rule for preverbal NPs to be definite. In detail, Topolinjska claims that a preverbal NP in Polish such as nauczyciel 'teacher' in her quotation below has to be translated by a definite article in Macedonian, which has postponed definite articles:
A Polish sentence of the type Nauczyciel wszedt do klasy [teacher came into classroom] has to be translated into Macedonian as Učitelot vleze vo oddelenieto [teacher.DEF came into class.DEF] 'The teacher came into the classroom' and this is the unique valid translation. Preverbal, i.e. unmarked position of the nominative NP signalizes that we are speaking about an identified teacher. (Topolinjska (2009: 184f.)

I have demonstrated that it is only a strong tendency, but not a general rule for preverbal NPs to be definite. This is only the case if the NP is topical. With respect to the (in)definite interpretation of post-verbal NPs there is no consensus in the Polish literature. For Szwedek (1974: 209, 1976b: 62), sentence-final NPs can only have an indefinite reading, which is also claimed by Topolinjska (2009: 184) writing

Finally, in a sentence of the type Do klasy wszedt jakiś nauczyciel lit. 'In the classroom came a (some) teacher' the post-verbal, marked position of the nominative NP, even without the lexical determiner [jakiś', signalizes the /- definite/ use.

(Topolinjska 2009: 184)

Topolinjska's claim is not correct concerning the Polish example she gives. If the indefinite pronoun jakis' 'some' is omitted, the post-verbal 
NP nauczyciel 'teacher' does not necessarily have to be interpreted as indefinite, but also allows for a definite reading in an appropriate context. This is why I follow Weiss (1983: 235), Mendoza (2004: 217) and Błaszczak (2001: 11), who argue that the post-verbal position allows for a definite and indefinite reading. Their claim for the unmarkedness of the post-verbal position is also supported by the investigation by Czardybon et al. (2014) presented above as well as examples like the one in (20). The definite interpretation of kierowca 'driver' is due to the fact that it is inherently unique. This clearly shows that the sentence-final position can also be associated with definiteness.

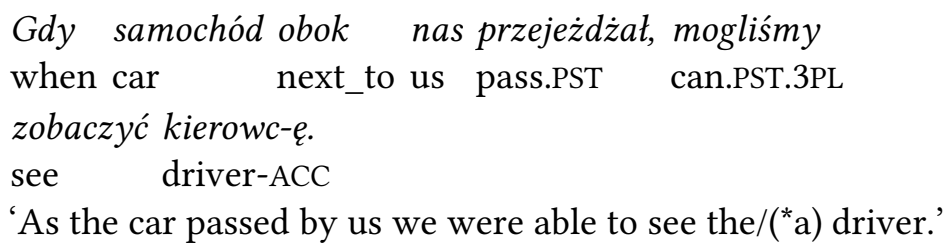

The discussion so far has clearly shown that a straightforward association between preverbal position and definiteness on the one hand and post-verbal position and indefiniteness on the other cannot be maintained.

Authors who associate the preverbal position with definiteness and post-verbal position with indefiniteness in Polish assume that demonstratives and indefinite pronouns are obligatory to overwrite definiteness by word order. Contrary to Sadziński (1982: 88), it is not the case that indefinite pronouns such as jakiś 'some' are obligatory to mark a preverbal NP as indefinite. This was already shown by the examples (17) and (18), in which the NPs are indefinite despite their preverbal position. Further evidence for the non-obligatoriness of indefinite pronouns in preverbal NPs is mentioned by Sadziński (1977: 82) himself in his analysis of translations of German texts into Polish. He points out that there are exceptions where an indefinite subject NP in German is not translated by using an indefinite pronoun with a preverbal NP in Polish. His explanation of these exceptions is that the translator has simply neglected to use them. My explanation is that they are simply not obligatory and can also be left out. On the other hand, demonstratives can explicitly 
mark a sentence-final NP as definite. However, this marking of definiteness is not obligatory in most cases, as with the [-U] concept ksiazika 'book' in (19b). This is why Szwedek's (1974: 208) claim cannot be maintained:

nouns with indefinite interpretation appear in sentence final position only (unless explicitly marked indefinite in some other way). This is why the pronoun ten is obligatory with a noun in this position if the noun is to be interpreted as definite. Nouns with definite interpretation appear in non-final positions (again, unless explicitly marked otherwise). (Szwedek 1974: 208)

Szwedek's quotation also shows that the distinction of concept types is crucial. In (20), the sentence-final NP kierowca 'driver' is a [+U] concept and only allows for a definite interpretation. The use of a demonstrative in this DAA example is not possible. The interaction between information structure and concept types is the topic of the next section.

\subsubsection{The concept type distinction and information structure}

So far, mostly sortal nouns have been analysed, whose definiteness is influenced by information structure. In (21), examples of individual nouns are given, such as the proper name fan as well as the lexical IN papiez 'Pope'. We have an unmarked sentence stress at the end of the sentence. The topical NP is fan in (21a) while the rest of the sentence represents the focus, thus we have predicate focus. In (21b), the word order is changed to OVS, which makes papiez 'pope' the topical NP, while $\mathrm{Fan}$ is focal. Thus, the sentences differ with respect to what is topic and what focus and thus the contexts in which the sentences can be uttered differ. In (21a), the referent of the NP Fan is taken for granted and given information whereas in (21b) it is the referent of the NP papie $\dot{z}$ 'pope'. However, information structure does not interact with the definiteness of INs. Independently of whether they are topical or not, they can only have a definite interpretation as singular bare NPs. This also holds for other INs. The NP papiez 'pope' can be replaced by the INs księżyc 'moon', stońce 'sun', or toponyms such as Londyn 'London' and Polska 'Poland' and all of them can only have a definite reading. 
a. Jan widziat PAPIEŻ-A.

Jan see.PST pope-ACC

'Jan saw the/(*a) Pope.'

b. Papież-a widziat JAN.

pope-ACC see.PST Jan

'Jan saw the/("a) Pope (It was Jan, who saw the Pope).'

Functional nouns behave similarly to individual nouns. They are interpreted as definite independent of whether they are the focus, as in (22a) with the FN matka 'mother', or the topic as in (22b) ${ }^{15}$ Here again, this observation is also true of other FNs such as ojciec 'father', kolor 'color', wysokość 'height', wtaściciel 'owner' and many more. In (22), the FN is the possessee while the possessor dziewczyna 'girl' is realized as a genitive attribute. Since the possessor is a sortal noun, its definiteness is influenced by information structure. As part of the focus, it can be definite or indefinite (22a), whereas it can only have a definite reading as part of the topical NP (22b). ${ }^{16}$
a. Jan widziat matk-e
DZIEWCZYN-Y.
Jan see.PST mother-ACC girl-GEN
'Jan saw the/(*a) mother of a/the girl.'
b. Matk-e dziewczyn-y widziat JAN.
mother-ACC girl-GEN see.PST Jan
'Jan saw the/(*a) mother of the/("a) girl.'

Relational nouns such as członek 'member' in (23) behave like sortal nouns with respect to the interaction of definiteness and information

FNs which are used without an explicit possessor also allow for an indefinite reading. The sentence in (i) can be uttered, for example, by a teacher to another teacher after a parents' evening and the FN matka 'mother' allows for an indefinite reading:

(i) Przyszła do mnie matka i mówi [...]

came to me mother and say.3sG

'A/the mother came to me and said [...]' 'the mother of a/the girl' is only definite if both nouns have a definite interpretation. According to Löbner (2011: 302f.), such a complex NP has unique reference iff all nouns within the NP have unique reference. 
structure. As part of the focus, they can have a definite or indefinite interpretation (23a), while as part of the topical NP they have a definite interpretation (23b). The possessor organizacja 'organization' in (23) is a sortal noun and shows the same behaviour as the $[-\mathrm{U}]$ concept czlonek 'member'.
a. Jan widziat członka ORGANIZACF-I.
Jan see.PST member.ACC organization-GEN
'Jan saw the/a member of the/an organization.'
b. Członka organizacj-i widziat JAN. member.ACC organization-GEN see.PST Jan 'Jan saw the member of the organization.'

The interaction of the four concept types with information structure provides evidence for the concept type distinction. Bare NPs with [+U] concept types have a definite reading only, independently of whether they are the topic or focus, whereas bare NPs with $[-\mathrm{U}]$ concepts are definite as topical NPs but definite or indefinite as focal NPs. Table 23 summarizes this result:

\begin{tabular}{|c|c|c|c|c|}
\hline & \multicolumn{2}{|c|}{$[+\mathrm{U}]$} & \multicolumn{2}{|c|}{$[-\mathrm{U}]$} \\
\hline & IN & FN & RN & SN \\
\hline Topical NP & \multirow{2}{*}{\multicolumn{2}{|c|}{ defini }} & \multicolumn{2}{|c|}{ definite } \\
\hline Focal NP & & & defin & efinite \\
\hline
\end{tabular}

Table 23: Interaction of concept types, information structure, and definiteness.

The result of table 24 might help to provide a clearer picture of the quantitative study presented in the previous section. This is why the nouns were annotated by two Polish native speakers with respect to inherent uniqueness and relationality: in order to make it possible to determine the underlying concept type of the nouns. The number of nouns in table 24 is smaller than in table 21 because nouns were not included, for example, if there was no agreement among the annotators. For more details concerning the annotation procedure and further reasons for excluding nouns see Czardybon \& Horn (2015). 


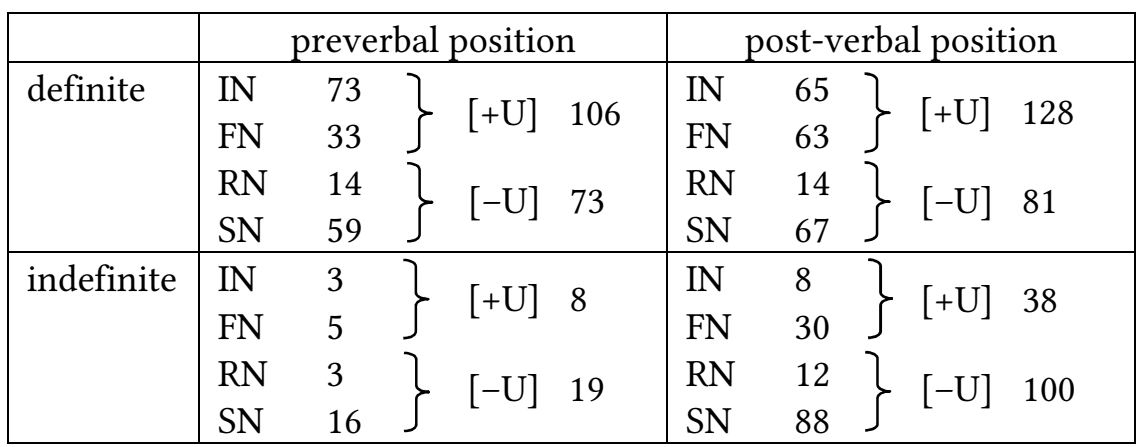

Table 24: Correlation between syntactic position, definiteness of NPs, and underlying concept type.

If we only focus on $[-\mathrm{U}]$ concept types which are sensitive to information structure, we can see that there is a small tendency for definite NPs to be placed post-verbally (73 preverbal vs. 81 post-verbal definite NPs). Definite NPs with underlying $[-\mathrm{U}]$ concept types in post-verbal position are due to anaphoric use (24a), NPs as heads of DAAs (24b), or NPs modified by complements establishing uniqueness (24c).

(24) a. Zanurzy-t stalówk-e $w$ atramencie $i$ zawaha-t się. dip-PST pen-ACC in ink.LOC and falter-PST REFL 'He dipped the pen into the ink and then faltered.'

(Orwell, translated by Mirkowicz 2008: 13)

b. Przemierzy-t pokój $i$ wszedt do maleńkiej cross-PST room and enter.PST to tiny.GEN kuchni.

kitchen.GEN

'He crossed the room into the tiny kitchen.'

(Orwell, translated by Mirkowicz 2008: 11)

c. Wrócit do pokoj-u $i$ usiadt przy come_back to room-GEN and sit_down.PST at stolik-u na lewo od teleekran-u. table.DIM-GEN on left from telescreen-GEN 'He went back to the living room and sat down at the small table that stood to the left of the telescreen.' (Orwell, translated by Mirkowicz 2008: 11) 
In (24a), the referents of the definite NPs stalówka 'pen' and atrament 'ink' have been introduced in the previous discourse and are mentioned again. The anaphoric NPs are placed post-verbally. In (24b), the NPs pokój '(living) room' and kuchnia 'kitchen' are heads of a DAA. The anchor mieszkanie 'flat' has been mentioned before, which is the flat of the protagonist called Winston. The NPs are also post-verbal, but interpreted as definite. In (24c), the uniqueness establishing PP na lewo od teleekranu 'to the left of the telescreen' leads to a definite interpretation of the postverbal NP stolik 'small table'.

The number of indefinite NPs with [-U] concept types in post-verbal position is higher than the ones with definite NPs (81 definite postverbal vs. 100 indefinite post-verbal NPs). This also shows that the postverbal position in general allows for a definite or indefinite reading. In contrast, the preverbal position is strongly associated with definiteness (73 definites vs. 19 indefinites). Indefinite NPs with [-U] concept types are found predominantly in post-verbal position (100 indefinite postverbal vs. 19 indefinite preverbal NPs).

There is also a small syntactic preference of definite NPs with [+U] concept types for the post-verbal position (128 post-verbal vs. 106 preverbal nouns). What table 24 also reveals is that bare NPs with [+U] concepts can be indefinite in preverbal ( 8 nouns) as well as in post-verbal position (38 nouns). This can be explained due to incongruent uses, for example, using an FN without a possessor as in (25) or using them in plural. The NPs twarz 'face' in (25a) is post-verbal while the FN gtos 'voice' in (25b) is preverbal and both have an indefinite reading. The NPs are modified by an adjective, but even without the adjectives the NPs would be interpreted as indefinite.
a. Przedstawiat tylko ogromn-q twarz, [...] depict.PST simply enormous-ACC face.ACC 'It depicted simply an enormous face, [...]' (Orwell, translated by Mirkowicz 2008: 7)
b. W mieszkani-u przejęty głos czytat kolumny cyfr [...] in flat-LOC fruity voice read.PST column figure.PL 'Inside the flat a fruity voice was reading out a list of figures' (Orwell, translated by Mirkowicz 2008: 8) 


\subsubsection{The ranking of concept types, information structure, and determiners}

So far, it has been shown that there are different strategies to express definiteness in Polish. These strategies interact in a complex way, which will be the topic in this section as well as in chapter 7. The question which will be investigated is what happens if two or more definiteness strategies come into conflict. Which strategy has the strongest impact and rules out the others and thus can be ranked highest? The previous section revealed that information structure has no influence on the definiteness of inherently unique nouns (FNs and INs) if they are used as bare singular NPs. This is why the $[+\mathrm{U}]$ concept types should be ranked higher than information structure (26).

$$
[+\mathrm{U}] \text { concept types }>\text { information structure }
$$

On the other hand, we have seen that the definiteness of $[-\mathrm{U}]$ concepts is influenced by information structure. As part of topical NPs, they only allow for a definite interpretation. This is why information structure should be ranked higher than $[-\mathrm{U}]$ concept types (27):

$$
[+\mathrm{U}] \text { concept types }>\text { information structure }>[-\mathrm{U}] \text { concept types }
$$

It has to be emphasized that $[+\mathrm{U}]$ concept types can be used as indefinite NPs. But explicit marking is often required, such as indefinite pronouns. In (28), the IN papiez 'Pope' has an indefinite reading due to the presence of the indefinite pronoun jakis' 'some'.

$$
\begin{aligned}
& \text { [...], ze jakiś papież zrobit } z \text { Rzymu naj-większy } \\
& \text { that INDEF pope made from Rome SPL-bigger } \\
& \text { burdel swiat-a? } \\
& \text { brothel world-GEN } \\
& \text { 'that some/("the) Pope made Rome into the biggest brothel } \\
& \text { in the world.' }
\end{aligned}
$$

The explicit marking of indefiniteness overwrites the unique reference of $[+\mathrm{U}]$ concepts. But it also overwrites the definite reading given by information structure with $[-\mathrm{U}]$ concept types. The SN kobieta 'woman' 
is preverbal and unstressed and would be interpreted most naturally as a definite and topical NP if it were not preceded by the indefinite determiner jakiś 'some'.

$$
\begin{aligned}
& \text { Jakaśs kobiet-e widziat JAN. } \\
& \text { INDEF.ACC woman-ACC see.PST Jan } \\
& \text { 'Jan saw some woman.' }
\end{aligned}
$$

These examples illustrate that the explicit marking of definiteness by means of determiners should be ranked higher than concept type and information structure (30).

(30) definite and indefinite determiners

$$
\begin{aligned}
& >[+\mathrm{U}] \text { concept types } \\
& >\text { information structure } \\
& \quad>[-\mathrm{U}] \text { concept types }
\end{aligned}
$$

This was the first step towards a ranking of definiteness strategies. In chapter 7, a ranking of all investigated strategies will be given which will serve as the basis for the construction of a decision tree.

\subsection{Slavic comparison}

Information structure in Slavic languages has been a topic of interest for some decades. However, it is not always the case that the interaction of definiteness with information structure is focused on. Authors such as Junghanns \& Zybatow (2009) and Yokoyama (2009) are only interested in the expression of information structure in Slavic without even mentioning that it interacts with definiteness, in contrast to Späth (2006), Sussex \& Cubberley (2006: 418), and Topolinjska (2009: 184f.). In this section, I will compare the Polish data to other Slavic languages. For this comparative part, I have chosen three Slavic languages representing each Slavic branch: Slovene (South Slavic), Czech (West Slavic), and Russian (East Slavic).

In Slovene, Russian, and Czech, it can also be observed that information structure influences the (in)definite interpretation of bare NPs. In Polish, post-verbal and stressed NPs are focal and can be either definite 
or indefinite. The same holds for Czech (31a). For the Russian postverbal NP poezd 'train' in (31b), Gladrow only gives an indefinite interpretation. For him, nouns which bear the sentence stress are interpreted as indefinite in Russian (Gladrow 1972: 648f.). According to Späth (2006: 59), the post-verbal stressed NP in (31b) can also have a definite reading. Slovene seems to differ from the other Slavic languages since, according to Sussex \& Cubberley, only an indefinite reading is possible. It should be checked whether the post-verbal NP in Slovene really allows only for an indefinite reading.

a. Czech (Cummins 1999: 179)

Přišel TElegram.

arrived telegram

'A/the telegram has arrived.'

b. Russian (Pospelov 1970, quoted after Gladrow 1972: 649;

Späth 2006: 59) ${ }^{18}$

prišel POEZD

arrived train

'The/a train arrived'

c. Slovene (Sussex \& Cubberley 2006: 420)

stric je darovál knjigo ${ }^{19}$

uncle AUX gave book

'uncle gave a book'

As in Polish, unstressed preverbal NPs are topical and get a definite interpretation in Czech (32a), Russian (32b), and Slovene (32c).

a. Czech (Cummins 1999: 177)

Postava stoí $v$ zahrade...$^{20}$

figure stands in garden

'The/*a figure is standing in the garden.'

Cummins (1999: 177, note 6) indicates sentence stress by bold face. To be consistent,

Sussex \& Cubberley (2006: 419f.) do not indicate the sentence stress in (31c), but 
b. Russian (Pospelov 1970, quoted after Gladrow 1972: 649)

poezd PRIŠEL

train arrived

'The train arrived'

c. Slovene (Sussex \& Cubberley 2006: 420)

knjigo je darovál STRIC ${ }^{21}$

book AUX give.PST uncle

'the book was given by uncle ${ }^{, 22}$

Three remarks concerning the examples in (32) have to be made. First, in the Czech example (32a), only a definite interpretation is given by Cummins for the post-verbal NP zahrade ' garden'. This is in contrast to the post-verbal NP telegram 'telegram' in (31a), which can have a definite or indefinite reading. The different behaviour with respect to definiteness seems to be due to the fact that the NP zahradĕ 'garden' is part of a PP. Also in Polish, bare nouns in PPs behave differently from nouns which are not part of a PP (33):
a. Ksiażka leży na STOLE.
book.NOM lie.3SG.PRS on table
'The book is lying on the table.'
b. Na stole leży KSIAZŻKA.
on table lie.3SG.PRS book.NOM
'A/the book is lying on the table.'

In both examples, the noun stót 'table' has a definite interpretation independently of its placement in the sentence. This does not mean that nouns in PPs always have a definite reading. Since nouns embedded in PPs seem to behave differently they will not be discussed in the following.

\footnotetext{
21 Sussex \& Cubberley (2006: 420) use bold face to indicate sentence stress in the Slovene examples. I use capital letters instead.

Sussex \& Cubberley (2006: 419) point out that the OVS word order in Slovene can be used to topicalize the direct object. In English, this is achieved by a passive construction (32c). The Slovene sentence is not a passive construction.
} 
The second remark concerns the post-verbal NP stric 'uncle' in the Slovene sentence (32c). This NP seems to be interpreted here as a name and is therefore not influenced by information structure as an IN and not used with a definite article in the English translation.

Third, Cummins (1999: 177f.) points out that in colloquial Czech preverbal bare NPs such as in (32a) require the demonstrative ten in many contexts. This is also a tendency in literary Czech (Uhlírová 1987: 110, quoted after Cummins 1999: 178). Furthermore, ten is obligatory with fronted NPs such as with knižku 'book' in (34) (Cummins 1999: 178, 198).

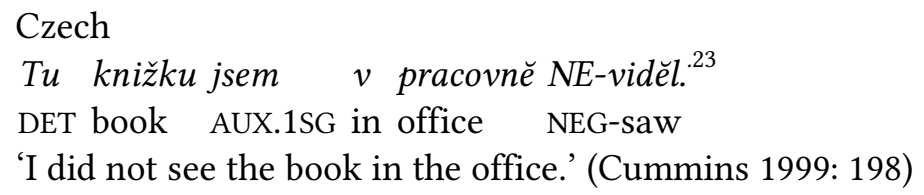

This is in contrast to Polish, where the preverbal position is sufficient for achieving a definite reading of an NP. The occurrence of a demonstrative to explicitly mark the NP as definite is not necessary.

For Polish, I showed that shifting the sentence stress to the preverbal NP changes the topic-focus structure of the sentence. This is why the preverbal NP is no longer interpreted as a topical NP, but becomes a focal one. A stressed preverbal NP allows for an indefinite but also a definite reading in Polish. The sentences in (35) have the same structure as the ones in (32), but the sentence stress is shifted to the preverbal NPs. Russian and Slovene differ from Polish since the preverbal stressed NPs can only have an indefinite reading, see (35b) and (35c). Czech also differs from Polish because a preverbal bare NP can only have an indefinite reading, if it is modified (35a) (Cummins 1999: 178f.). However, there is interspeaker variation in the acceptability of the sentence since Cummins (1999: 178) writes "[f]or some [speakers], contrastive intonation can overcome position rules and introduce a specific indefinite." Without bearing the sentence stress, the preverbal NP neznámá postava would be definite (Cummins 1999: 178). To get an indefinite NP in preverbal position which is accepted by all speakers, an indefinite pronoun nĕjaká

23 The translation of $t u$ as a definite article by Cummins (1999: 198) could be understood as if Czech had a definite article, which is not the case. 
'some' has to be used in (35a), according to Cummins (1999: 178). In Polish, the effect of word order can be overridden by sentence stress without any problem. No modifier or indefinite pronoun has to be added to the stressed preverbal NP in order to achieve an indefinite reading of the NP. The contrast between Polish and Czech reveals that the preverbal position in Czech is more associated with definiteness than in Polish.

a. Czech (Cummins 1999: 179)

?NEznámá POstava stoí $v$ zahradĕ. unknown figure stands in garden

'A strange figure is standing in the garden.'

b. Russian (Pospelov 1970, quoted after Gladrow 1972: 649)

POEZD prišel

train arrived

'A train arrived'

c. $\quad$ Slovene (Sussex \& Cubberley 2006: 420)

KNfIGO je darovál stric

book AUX gave uncle

'it was a book that uncle gave'

Table 25 summarizes the results of the interaction between information structure and definiteness in the four languages investigated:

\begin{tabular}{|c|c|c|c|}
\hline & Topical NP & \multicolumn{2}{|c|}{ Focal NP } \\
\hline & $\begin{array}{c}\text { preverbal and } \\
\text { unstressed }\end{array}$ & $\begin{array}{l}\text { post-verbal } \\
\text { and stressed }\end{array}$ & $\begin{array}{c}\text { preverbal and } \\
\text { stressed }\end{array}$ \\
\hline Polish & \multirow{4}{*}{ definite } & \multirow{3}{*}{ definite/indefinite } & definite/indefinite \\
\hline Russian & & & indefinite \\
\hline Czech & & & (indefinite) $^{24}$ \\
\hline Slovene & & indefinite & indefinite \\
\hline
\end{tabular}

Table 25: Summary of the interaction between information structure and definiteness in Polish, Czech, Slovene, and Russian with $[-\mathrm{U}]$ nouns.

24 The brackets indicate that an indefinite interpretation is not accepted by all Czech informants even if the NP is modified. 
For Polish, I demonstrated that bare NPs with INs only allow for a definite reading independently of their placement within the sentence. The same holds for other Slavic languages. This is exemplified by the postverbal IN solnce 'sun' from Russian (36a) and the post-verbal FN konec 'end' from Czech (36b):

(36) a. Russian (Fedorov 1958: 191, quoted after Birkenmaier 1979: $58 \mathrm{n})$

vzošlo solnce

rose sun

'the sun rose'

b. Czech

To je konec (toho) filmu.

DEM COP end DEM film.GEN

'This is the end of the film.'

It has been shown that the (in)definite reading of inherently non-unique concepts depends on information structure in articleless Slavic languages. What about languages with articles? Does information structure influence the definiteness of NPs in such languages? For Polish, I demonstrated that explicit marking such as definite and indefinite determiners can overwrite the influence of information structure. It is not surprising that in languages with articles, which explicitly mark an NP as definite or indefinite, information structure does not interact with definiteness.

The following German examples illustrate this point. Independently of their syntactic position, NPs can be definite or indefinite marked by the definite or indefinite article. ${ }^{25}$ (37a) shows that preverbal unstressed and post-verbal stressed NPs can be definite or indefinite, whereas (37b) exemplifies that the same holds for preverbal stressed and post-verbal unstressed NPs.

25 Only indefinite singular count nouns are marked by the indefinite article in German. Indefinite plurals and mass nouns are not marked as indefinite explicitly. 
German
a. Die/eine Frau liest das/ein BUCH.
DEF/INDEF woman read.3SG DEF/INDEF book
'The/a woman is reading the/a book.'
b. Die/eine FRAU liest das/ein Buch.
DEF/INDEF woman read.3SG DEF/INDEF book
'The/a woman is reading the/a book.'

The same can be observed in Bulgarian, which is illustrated by (38). ${ }^{26}$ In both examples, either the preverbal or the post-verbal NP can be stressed or not, which does not change the definiteness of the NPs: ${ }^{27}$
Bulgarian $^{28}$
a. Žena-ta čete edna kniga.
woman-DEF read.PRS.3SG one book
'The woman is reading a/one book.'
b. Edna kniga čete žena-ta.
one book read.PRS.3SG woman-DEF
'The woman is reading a/one book.'

\subsection{Conclusion}

Information structure primarily concerns an optimal structuring of the information one wants to convey. We started with the distinction between thetic and categorical sentences, whereby the latter consist of a topic and a focus. The results of table 23 are integrated into figure 3.

There is much debate about whether edin in Bulgarian has the status of an indefinite article or is still a numeral for 'one'. For a discussion see Geist (2013).

Although Bulgarian has lost almost all morphological case marking it has a "free" 


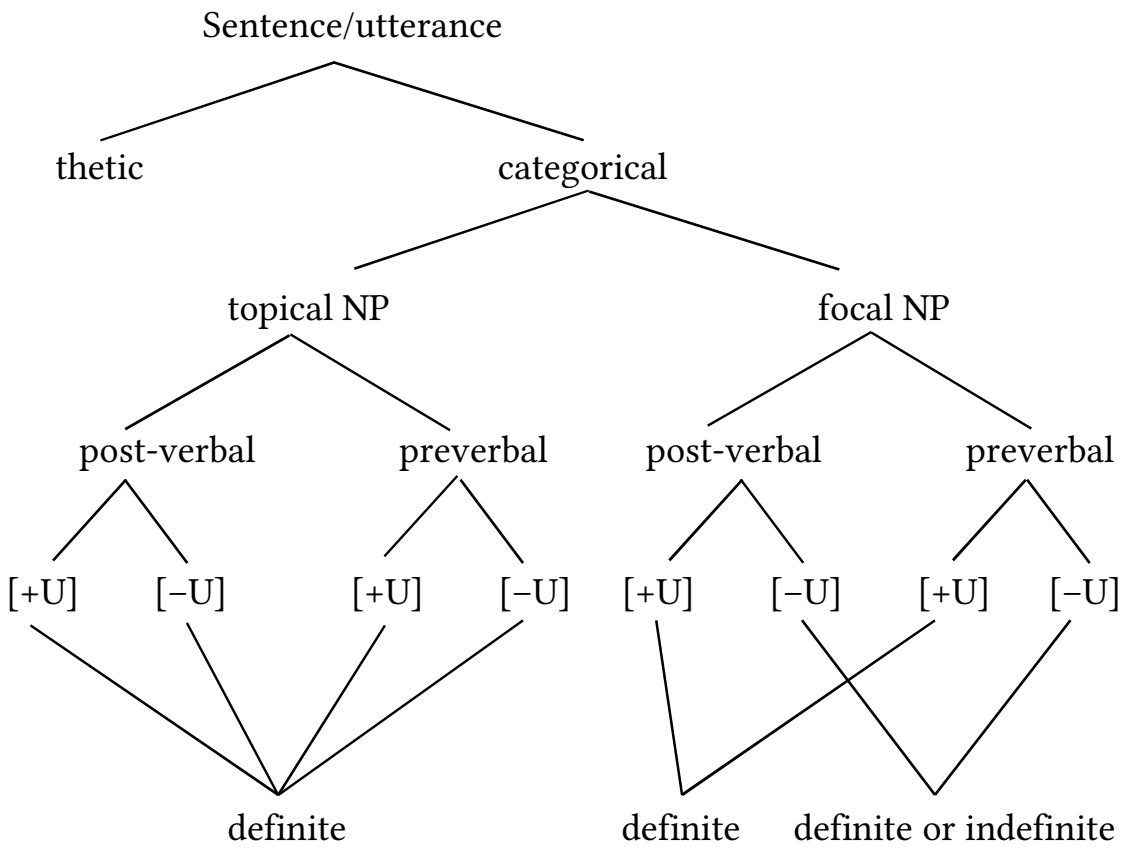

Figure 3: The interaction between information structure, word order, concept types, and definiteness in Polish.

The topic contains the presupposed proposition, thus information which is taken for granted and given for the speaker and the hearer, whereas the focus is the added or new proposition. It has been shown that information structure is associated with word order and sentence stress in Polish and other Slavic languages. In Polish unmarked sentences, topical NPs are found preverbally while focal NPs are post-verbal. However, topical NPs can also be post-verbal and focal NPs preverbal, which shows that we can find topical and focal NPs in all syntactic positions. Topical NPs can only be interpreted as definite (or generic, or partitive) regardless of the concept types. In contrast, focal NPs can be definite or indefinite if the noun is not a $[+\mathrm{U}]$ concept type. Inherently unique nouns keep their unique reference even as focal NPs as long as they are not explicitly marked as indefinite or used incongruently such as in plural or without a possessor in the case of FNs. 
The quantitative study carried out by Czardybon et al. (2014) provides evidence against the claim that every preverbal NP is definite. This is only a tendency due to the unmarked preverbal position of topical NPs which are definite. The correlation between the syntactic position of an $\mathrm{NP}$ and its definiteness is thus more complex since this depends on the topic-focus structure, which can be changed to focus-topic by, for example, shifting the sentence stress to the preverbal NP or by using explicit marking. Regarding figure 3 from the bottom, an indefinite preverbal NP implicates a focal use of this NP, whereas a definite preverbal NP can be focal or topical.

The comparative study revealed that there is micro-variation with respect to the definiteness of focal NPs in the Slavic languages. This chapter also provides the first step towards a ranking of the investigated definiteness strategies, which interact in a complex way and will be a crucial point of investigation in the next chapter. 
